\title{
A Comparative Review of the Literature on Pakistani Science Teachers' Professional Development
}

\author{
Azhar M. Qureshi', Kadir Demir* \\ ${ }^{1}$ University of Education Lower Mall Campus, Lahore, Pakistan, ${ }^{2}$ Department of Middle and Secondary Education, Georgia State University, Atlanta, \\ Georgia, United States of America
}

*Corresponding Author: kadir@gsu.edu

\section{ABSTRACT}

Pakistan, like many other countries of the world, has continually been criticized for its unproductive professional development (PD) policies and practices for teachers due to low student achievement in science disciplines. A good portion of science teachers (62\%) in Pakistan was found to be uncomfortable in teaching the scientific concepts (National Education Assessment System [NEAS], 2014) and PD programs are failing to address this issue. There is a need to reconstruct the operationalized knowledge of PD for Pakistan to expand the ways of knowledge creation, examination, authentication, and distribution. This also implies the need to review the current western literature on PD designs and practices to explore the ways of addressing the issues of Pakistani PD programs. With this purpose in mind, the current study set out to search the comparative understanding of science teachers' PD learning and experiences in Pakistan. The study was carried out to review the literature on science teachers' PD learning and experiences in the Western context (The US and European countries) while comparing it with the situation of Pakistani science teachers' PD practices. This seeks to address the critical questions of how to increase the effectiveness in Pakistani PD practices.

KEY WORDS: professional development; science; teachers; Pakistan

\section{INTRODUCTION}

ᄂ

eacher professional development (PD) refers to those programs designed to assist teachers in improving their knowledge, skills, and motivation to increase learning and student achievement (Melville and Yaxley, 2009; Whitworth and Chiu, 2015). Teachers' role in the inception, implementation, and evaluation of PD is central to successful and sustained PD programs (Luneta, 2012). According to Hargreaves and Shirley (2012), meaningful PD relies on the individual teacher realizing a need to think and work differently. It can be implemented through participation in formal PD programs or by becoming a member of professional learning communities. For in-service science teachers, PD learning offers varied opportunities to build capacity for informed decision-making, transformation in their instructional practices and ultimately, student outcomes (Smith and Lindsay, 2016).

Internationally, it is well accepted that PD for science teachers is critical for the success of science education. However, PD activities are under constant criticism by researchers as teachers largely fail to apply the intended goals of those activities in their classrooms, resulting in little or no improvement in the student learning outcomes (Buczynski and Hansen, 2010). The findings from Programme for International Student Assessment, Trends in International Mathematics and Science Study (TIMSS), and in Eurydice studies of European countries (2007-2009) highlight that regardless of the PD programs, the traditional approaches of teaching science are still dominant in schools in Europe (Scheerens, 2010). The situation is even worse in Africa and in many countries in Asia, where science teachers lack sufficient resources, rejects research-based changes to the methodology, and is characterized by an overall reluctance to accept change.

Pakistan, like many other countries of the world, continually receives criticism for its unproductive PD policies and practices for teachers due to low student achievement in science. A good portion of science teachers (62\%) in Pakistan was found to be uncomfortable with teaching the scientific concepts (NEAS, 2014) and PD programs are failing to address this issue properly. Pakistan must shift the way $\mathrm{PD}$ is examined and implemented to reconstruct the operationalized knowledge of PD effectively. This will result in the authentic improvement of professional learning. Another useful approach is to review the current western literature on PD practices and apply those practices to current Pakistani PD programs. With this purpose in mind, the current study set out to search the comparative understanding of science teachers' PD learning and experiences in Pakistan. The study includes a comparative review of the literature on science teachers' PD learning and experiences in the Western context (The US and European countries) with Pakistani science teachers' PD practices with the objective of addressing critical questions of how to increase the effectiveness of Pakistani PD practices. 


\section{METHOD OF THE LITERATURE REVIEW}

For the literature review, ScienceDirect, ERIC, and EBSCO hosts were used as the main search engines, including a rigorous document search on Google and Google Scholars. The term PD was held constant due to its centrality to the review. A variety of terms such as science teacher learning, learning effectiveness, science teacher practices, science teachers' needs, science teachers' experiential challenges, learning challenges and issues, and science teachers' strategies, with both British and American spellings were used to search the databases. For the Western contexts, research articles published in peer-reviewed journals between 2001 and 2018 were used as the primary source of the review, while some books and book chapters served as a secondary source. For the Pakistani context, the literature selection included only research articles, reports, and official documents published in English that contained information on Pakistani science education. This review was limited to the literature on science teachers' PD efforts at the K-12 school level for both contexts.

The following research questions were addressed:

1. What is the focus of the literature on science teachers' PD learning and experiences in the Western context? How do the different features of PD learning and experiences support or impede PD effectiveness?

2. What is the focus of the literature review on science teachers' PD learning and experiences in the Pakistani context? How do the different features of PD learning and experiences support or impede PD effectiveness?

3. What implications do the information gathered from the literature review have for Pakistani policymakers and researchers for developing research programs in studying PD programs and designing effective PD programs?

The first part of the review considers the science teachers' PD learning and experiences in the Western context. The second part of the literature review concentrates on Pakistani science teachers' PD learning and experiences. The third part of the literature review, discussion and conclusion compares the Pakistani science teachers' PD learning experiences with that of the Western context and concludes with implications for how to improve PD learning experiences for Pakistani stakeholders.

\section{SCIENCE TEACHERS' PD LEARNING AND EXPERIENCES IN WESTERN CONTEXT}

Science teachers' PD is viewed as an ongoing learning experience that spans the entirety of the teaching profession (Desimone, 2009; Guskey, 2002). It includes activities from formal, highly structured topic-specific seminars provided on PD days to everyday, informal discussions between science teachers. Likewise, PD is the primary approach that schools use to ensure that teachers are continually strengthening their practices with research-based methods aimed improving at their pedagogical content knowledge (PCK), nurturing critical thinking, and increasing problem-solving skills (Desimone et al., 2002). The purpose of an effective PD program is to bring about positive changes in the participants' professional life so that they can interact with their social and cultural realities (Buczynski and Hensen, 2010). The most effective PD practices are those that focus on science teachers as individuals and results in sustainable changes in teachers' learning and practice (Desimone et al., 2002). These PD practices require that science teachers be participants in the identification of their learning needs. Effective PD can result in changing science teachers' practices by enhancing their professional experiences, personal epistemologies, openness, and willingness for change (Asghar et al., 2012; El-Hani and Greca, 2013; Guskey and Yoon, 2009; Lee and Buxton, 2013).

Teacher learning outcomes are shaped through PD structure, design, and objectives. An extensive body of the literature was reviewed to determine the following: Impacts of PD on science teacher learning and experiences (Bell and Odom, 2012; Eilks and Markic, 2011; Opfer and Pedder, 2011; Posnanski, 2010); science teachers' growth and change (Akiba, 2012; Banilower et al., 2007; Goodnough, 2010; Melville and Yaxley, 2009; Ramlo, 2012; Tan and Nashon, 2013); positive relationship with instructional practices (Beamer et al., 2008; Desimone et al., 2002; El-Hani and Greca, 2013; Kazempour, 2009; Lee and Buxton, 2013; Smith, 2015); reflective practices (Capobianco and Feldman, 2006; Mamlok-Naaman and Eilks, 2012; McNicholl and Blake, 2013; Saylor and Johnson, 2014; Tang and Shao, 2013); and science teachers' self-perception (Allen and Penuel, 2015; Lustick, 2011; Mikelskis-Seifert and Duit, 2013; Mokhele and Jita, 2010; Torff and Byrnes, 2010).

Researchers have also measured the impact of PD learning activities on instructional effectiveness by measuring student outcomes. For instance, students' classroom achievements were evaluated by assessing their attitudes toward science learning (Adamson et al., 2013; Diamond et al., 2014; Foster et al., 2013; Herman et al., 2013; McNeill and Knight, 2013; Oliveira et al., 2013; Santos and Oliveira, 2006; Sinclair et al., 2010; Sullivan-Watts et al., 2013).

To make PD practice relevant, useful, and meaningful, it is essential to consider the positive experiences of teachers (Guskey, 2002; Sexton et al., 2013). Presently, western literature focuses on the specific ways wherein science teachers learn and experience during PD activities and the ways in which PD programs support teachers' changing attitudes and beliefs toward science teaching (Imants, 2002; Park et al., 2015; Visser et al., 2013).

\section{A Brief Literature Review on Learning and Experiences} of Science Teachers in the Western Context through PD

Researchers have asserted that evaluating the effects of PD programs on science teachers' learning is a complex process (Allen and Penuel, 2015), which varies across the context of the school environments (Luft and Hewson, 2014). According to Garet et al. (2001), a majority of researchers agreed on what establishes effective PD activities. Despite this, there is only limited literature available on the issue as to how these activities are translated into teachers' professional learning 
(Loughran, 2013; Opfer and Pedder, 2011; Smith and Lindsay, 2016). The literature shows that there is no singular model that demonstrates best practices of PD that affect teachers' learning experiences (Lustick, 2011). However, to understand how science teachers learn, it is essential to investigate multiple contexts and factors in and with which they work (Borko, 2004).

\section{Active learning experiences}

Five features of effective PD learning and experiences have been commonly identified through research studies, these include: Focus on content, active learning, coherence, sufficient duration for practice, and reflection on PD learning experiences (Desimone, 2009; Guskey, 2002, Hynds et al., 2011; Tytler et al., 2001; Zientek, 2014). Similarly, several other researchers have included additional features of PD learning experience to the list. A synthesized view of different features of science teachers' PD learning and experiences, along with an operational definition of each feature is briefly provided in Table 1 and explained subsequently.

The literature on effective PD learning and experiences gave special emphasis to "active learning" which is based on the view of describing learning wherein the learner interacts with the information and experiences (Garet et al., 2001). According to Desimone et al. (2002) and Saylor and Johnson (2014), effective PD learning and experiences entail active participation of science teachers in the PD process. Active learning experiences have a positive impact on teachers' practices through building their motivation, reflective thinking, personal epistemologies, attitude change, openness, and willingness to change (Akiba, 2012; Santos and Oliveira, 2006). Furthermore, active learning has the potential to result in more sustained change compared to other forms of learning.

\section{Knowledge and belief construction}

The evaluation of changes in science teachers' beliefs as a result of their participation in PD is a complex process and consists of interactions between PD learning, school contexts, and teachers' beliefs of science (Deniz and Akerson, 2013; Gao and Wang, 2014; Kazempour and Amirshokoohi, 2014; Posnanski, 2010). Research studies suggested that science teachers' existing ideas, beliefs, experiences, concerns, interest, and feelings toward PD programs are important criteria to consider in the development of effective PD activities (Aflalo, 2013; Dare et al., 2014; Lotter et al., 2013).

Table 1: A synthesized review of the literature on science teachers' PD learning and experiences in the Western context

\begin{tabular}{|c|c|c|}
\hline Features & Key findings(s) & Contributed scholar(s) \\
\hline $\begin{array}{l}\text { Active learning } \\
\text { experiences }\end{array}$ & $\begin{array}{l}\text { PD experiences provided to science teachers } \\
\text { have an impact on science teachers' instruction } \\
\text { approaches }\end{array}$ & $\begin{array}{l}\text { Akiba, 2012; Desimone et al., 2002; Garet et al., 2001; } \\
\text { Greene et al., 2013; Saylor and Johnson, 2014; Smith } \\
\text { and Lindsay, } 2016\end{array}$ \\
\hline $\begin{array}{l}\text { Knowledge and } \\
\text { beliefs construction }\end{array}$ & $\begin{array}{l}\text { Science teachers' PD knowledge construction } \\
\text { depends on their existing knowledge and beliefs }\end{array}$ & $\begin{array}{l}\text { Allen and Penuel, 2015; Banilower et al., 2007; Berry } \\
\text { et al., 2009; Crippen, 2012; Heck and Crawford, 2004; } \\
\text { Holbrook et al., 2014; Lotter et al., 2013; Torff and } \\
\text { Byrnes, 2010; Zwiep and Benken, } 2013\end{array}$ \\
\hline Learning needs & $\begin{array}{l}\text { What they already know and what they need to } \\
\text { learn should be emphasized and improved on }\end{array}$ & $\begin{array}{l}\text { Bernhardt, 2015; Nir and Bogler, 2008; Petrie and } \\
\text { McGee, 2012; Ramlo, 2012; Roseler and Dentzau, } \\
2013\end{array}$ \\
\hline Follow-up experiences & $\begin{array}{l}\text { Effective PD programs contain follow-up } \\
\text { experiences with multiple interactions }\end{array}$ & $\begin{array}{l}\text { Antoniou and Kyriakides, 2013; Coenders et al., 2010; } \\
\text { Eilks and Markic, } 2011\end{array}$ \\
\hline Teacher research & $\begin{array}{l}\text { Teachers learn through their action research } \\
\text { opportunities to make an informed decision about } \\
\text { instruction }\end{array}$ & $\begin{array}{l}\text { Baumfield, 2007; Capobianco and Feldman, 2006; } \\
\text { Corte et al., 2013; Harnett, 2012; Mamlok-Naaman } \\
\text { and Eilks, 2012; Rathgen, } 2006\end{array}$ \\
\hline Reflective practices & $\begin{array}{l}\text { Examining of current and past professional } \\
\text { practices and improving future practices through } \\
\text { problem-solving strategies }\end{array}$ & $\begin{array}{l}\text { Beamer et al., 2008; Bocala, 2015; Faber et al., 2014; } \\
\text { Henze et al., 2009; Mamlok-Naaman and Eilks, 2012; } \\
\text { Muir et al., 2010; Van Driel et al., } 2001\end{array}$ \\
\hline $\begin{array}{l}\text { Communities of } \\
\text { practice }\end{array}$ & $\begin{array}{l}\text { The activities of professionals such as coaching, } \\
\text { teaming, partnerships, and other collective efforts } \\
\text { have positive impacts on both instructional } \\
\text { practices and student achievements }\end{array}$ & $\begin{array}{l}\text { Akiba, 2012; Boyle et al., 2004; Cox-Petersen et al., } \\
\text { 2005; El-Hani and Greca, 2012; Eilks and Markic, } \\
\text { 2011; Goodnough, 2010; Howe and Stubbs, 2003; } \\
\text { Ngcoza and Southwood, 2015; Owston et al., 2008; } \\
\text { Patton et al., } 2013\end{array}$ \\
\hline $\begin{array}{l}\text { Leadership and } \\
\text { organizational support }\end{array}$ & $\begin{array}{l}\text { School principals, through their deliberate actions, } \\
\text { need to identify, allocate, and support resources } \\
\text { for teachers' professional learning }\end{array}$ & $\begin{array}{l}\text { Buczynski and Hansen, 2009; Hobbs, 2012; Imants, } \\
\text { 2002; Lovett and Cameron, 2011; Masuda et al., 2013; } \\
\text { Oliveria et al., 2013; Opfer and Pedder, 2011; Rhodes } \\
\text { and Beneicke, 2002; Sandholtz and Ringstaff, 2016; } \\
\text { Whitworth and Chiu, } 2015\end{array}$ \\
\hline $\begin{array}{l}\text { Participation } \\
\text { experience }\end{array}$ & $\begin{array}{l}\text { Positive teachers' experiences of participation } \\
\text { make PD learning relevant, useful, and meaningful }\end{array}$ & $\begin{array}{l}\text { Guskey, 2002; Kazempour and Amirshokoohi, 2014; } \\
\text { Kwakman, 2001; Lalor and Abawi, 2014; Lustick, } \\
\text { 2011; Mikelskis-Seifert and Duit, 2013; Nielsen, 2012; } \\
\text { Sexton et al., 2013; Roux, 2013; Saunders, 2012; } \\
\text { Seidel et al., 2011; White et al., } 2010\end{array}$ \\
\hline
\end{tabular}


There is a growing consensus among researchers that $\mathrm{PD}$ programs must emphasize CK and PCK to create highly effective PD learning experiences. Researchers have used PCK as an indicator of science teachers' learning after PD activities (Banilower et al., 2007; Garet et al., 2001; Zwiep and Benken, 2013).

\section{Learning needs}

Another crucial element to be considered in PD learning and experience is to match the PD programs with science teachers' learning needs. Science teachers' learning needs can be explored by placing focus on needs during the PD design and implementation. A major shortcoming noted by researchers who have studied PD programs for science teachers is that many PD programs fail to consider factors such as teachers' views, perceptions, and needs (Capobiano et al., 2006; Hermann, 2013; Holbrook et al., 2014; Kazempour and Amirshokoohi, 2014).

\section{Follow-up experiences}

The amount of feedback and continued support offered to science teachers is also critical in the effectiveness of PD programs (Bernhardt, 2015). To ensure effective PD learning and experiences, PD developers are expected to set explicit teacher learning goals. There is a need to support science teachers' implementation of PD learning and assess them through follow-up activities to ensure that science teachers apply their PD learning and experiences (e.g., Antoniou and Kyriakides, 2013; Boyle et al., 2004). By engaging in such follow-ups, a coherence between the PD designs, instructional practices, and learning environment is established (Coenders et al., 2010; Eilks and Markic, 2011).

\section{Teacher research}

Teachers who inform and improve on their practices conduct teacher research or action research. It is predominantly considered to be a Western concept as a means to empower science teachers who want to increase knowledge about their own practices (Baumfield, 2007; Capobianco and Feldman, 2006; Harnett, 2012). The core conceptions of teaching significantly change when teachers engage in action-related research activities. This job-embedded approach engages teachers in meaningful and purposeful ways during and after $\mathrm{PD}$ and brings about effective professional learning in teachers (Corte et al., 2013). Different studies have emphasized that research-based PD experiences can influence the motivation of science teachers. Likewise, their action-research or participatory experiences can help them in their transition from a guided experience to freedom, making them feel useful and motivated (Faber et al., 2014). Their voices, viewpoints, and experiences as researchers empower them to play active roles in PD learning (Capobianco et al., 2006).

\section{Reflective practices}

Reflective practices involve the mental process of reflection and are considered to be a STRONG critical feature of PD learning and experiences. Through reflective practices, science teachers can effectively increase their competence to reflect critically on both the curriculum framework and the circumstances in which they have to work (Mamlok-Naaman and Eilks, 2011). Further, reflective practices have been recognized as a popular feature that aids the understanding of PD, empowerment, and decision-making, as well as students' outcomes (Bocala, 2015; McCullagh, 2012; van Driel e al., 2001). Teachers can personalize their professional learning and experiences through reflective research practices (Corte et al., 2013; Çimer and Paliç, 2012).

\section{Communities of practices}

PD learning through the community of practices have been found to result in positive practice outcomes among science teachers (Howe and Stubbs, 2001; Kazempour and Amirshokoohi, 2014; Sexton et al., 2013; Tang and Shao, 2014). When science teachers work as members of professional learning communities, their PD learning and experiences surpass participating in a single PD program; it is continuously shaped through social interactions (Boyle et al., 2004; Eilks and Markic, 2011). Vázquez-Bernal et al. (2012) mentioned, "teachers do not easily change their conceptions, and even less so, their educational practices" (p. 338). Thus, teachers need to continue to learn with the emotional support of a community of practice to gain a solid knowledge of the content (McNicholl and Blake, 2013).

\section{Leadership and organizational support}

In past few decades, an emphasis has been placed on the role of leadership and organizational support in building the capacity of the science teacher workforce during PD (Buczynski and Hansen, 2009; Imants, 2002; Opfer and Pedder, 2011; Sandholz and Ringstaff, 2016; Whitworth and Chiu, 2015). School leaders have a central role to play in supporting PD learning and experiences through developing teacher leadership and cultivating learning communities. Different organizational conditions and the availability of resources can also produce contexts that allow teachers to benefit more from PD learning opportunities.

\section{Participation experiences}

Teacher's participation in PD and experiences is considered to be a critical feature of teacher's learning and change. A successful PD program helps teachers acquire meaningful experiences and enables them to implement new ideas in schools (Banilower et al., 2007; Kazempour, 2009). However, participation in different PD experiences is embedded in temporal flows and sometimes standout as disruptive or unmotivated actions (Daugbjerg et al., 2015). Studies have shown that science teachers' learning and experiences are evolving in specific PD situations. These meaningful experiences are, mostly, based on teachers' attitudes toward PD. Those teachers who are intensely motivated to attend the PD programs are likely to learn and change after participation.

\section{Issues Observed in the Effectiveness of PD Programs in the Western Context}

The research identified a number of ineffective features of PD programs for science teachers' learning and experiences. These included fragmentation, lack of implementation, and lack of teacher-centeredness (Lustick, 2011). For many teachers, 
learning was perceived as a general activity instead of being a concept building or a discipline-specific activity (Zhang et al., 2015). Thus, the sustainability of PD learning and experiences become a challenge. Most PD programs appear to use traditional approaches that are not helping teachers revise what or how to teach (Borko, 2004; Wallace, 2013). Loucks-Horsley et al. (2009) stated that most PD programs do not feature a well-designed and continuous support system and are incapable of effectively addressing science teachers' learning needs. Because teachers' racial, historical, and curricular perceptions and challenges of participation in PD learning are not taken into account in the design, implementation, or improvement of the programs (Atwater et al., 2013); these programs can be ineffective. Similarly, some PD programs did not take the attitudes of science teachers into consideration (Boyle et al., 2004; Maskit, 2013; Torff and Byrnes, 2011).

Science teachers also perceive PD as fragmented, confusing, and unrelated to the issues they have regarding instructional practices (Lieberman and Mace, 2008). Current PD practices are imposed on teachers, reducing their power to choose their own objectives and methods, thus weakening their professionalism and efficacy. This leaves teachers to act as specialists, simply implementing someone else's design (McCullough et al., 2000) rather than being able to apply authentically what they have learned.

The literature on PD learning and experiences of science teachers in this paper can be categorized in two areas: (a) The fundamental features of science teachers' PD learning and experiences and (b) the organizational features of leadership. The fundamental features of science teachers' PD learning and experiences include experiences of active learning, participation, follow-up, collaboration, teacher research, and reflective practices. The organizational features of leadership, on the other hand, comprise a community of practices, support, and follow-up experiences. Features from those two categories are interwoven, and ultimately together, they influence PD programs' effectiveness.

\section{Science Teachers' PD Learning and Experiences in Pakistani Context}

The current practices of science teachers' PD in Pakistan are provided through a single workshop or at best, a series of sessions. Teachers in public sectors utilize the traditional Cascade model to instigate PD learning. Most of the PD programs emphasize the effectiveness of teachers by stressing the technical aspects of their profession (Ali, 2011). This section of the review explores the PD learning and experiences of science teachers in Pakistan, which is segregated into two subsections. The first section focuses on providing a brief background of the Pakistani PD structures and reform efforts for enhancing science teachers' learning while exploring the effectiveness of PD. The second section concentrates on the exploration of relevant literature that focuses on different facets of science teachers' learning and experience, and challenges associated with PD programs' effectiveness.

\section{Background and structure}

Pakistan's independence in 1947 initiated various reform efforts to bring about quantitative and qualitative changes in science teachers' learning and experiences. In 1950, science as a subject was offered in primary and middle schools. In 1959, the Pakistan Government began focusing on science teaching and recommended science as a compulsory subject for Grade Levels 6 through 8 (Iqbal and Mahmood, 2000). Several of the past educational policies (1959-2009) have shifted the emphasis from the teaching of science at the school level to of the importance of science and technology education in the country (Government of Pakistan, 2009). One of the most significant efforts for promoting the quality of science teaching at the national level came in 1984 with the help of the Asian Development Bank and Organization of the Petroleum Exporting Countries with the implementation of Science Education Projects (SEP). The government initiated this unique institutionalized effort to improve PD strategies for science teachers' professional learning. Through this effort, providing laboratory resources, school equipment, revising science curricula, and providing PD to science teachers enhanced the basic capacities of institutions.

The National Institute of Science and Technical Education (NISTE) was established in 2004 with the purpose of creating awareness among stakeholders for the development of science teaching skills. NISTE organized more than 500 PD programs between 2005 and 2008 on the discipline of science, mathematics, computer, and technologies for technical training. The institute trained 2603 science and technical teachers during the first 4 years of establishment. These PD programs provided an opportunity for science teachers to expand, learn new information, and share their knowledge, expertise, and experiences (Government of Pakistan, 2009). NISTE, between the years 2009-2012, implemented the project for the promotion of student-centered and enquiry-based (SCIB) science education. As a part of this project, a revised version of the national curriculum for science was introduced and new PD models based on SCIB science lessons were included in the study.

For instance, in the Punjab Province of Pakistan, significant changes took place regarding science teachers' PD under the SEP-1 and SEP Phase-II (1999-2007). Because of these initiatives, the emergence of 71 Regional Training Centers, 302 multi-purpose laboratories and 298 mathematics resource rooms were provided at the secondary level. To improve capacity, around $28,000+$ heads of schools and science teachers' PD training in the subject of physics, chemistry, biology, mathematics, general science, and computers were implemented. Furthermore, 43 science teachers received foreign training in Australia and Malaysia for 5 weeks (Government of the Punjab, 2012). In 2004, the directorate of staff development (DSDs) was established as an apex organization to monitor the public-sector education scheme through a framework of continuous PD to ensure quality learning among science teachers. Along with the DSDs, 
different public sector institutions such as the University of Education, Institute of Educational Research, and Provincial and Regional Institutes of Teacher Education provided different types of science teacher in-service PD training at elementary and secondary levels.

\section{A Brief Literature Review on PD Learning and Experiences of Science Teachers in Pakistan}

Studies conducted in Pakistan revealed that professional learning outcomes are produced through several effects such as socioeconomic, spiritual, and collective structures of individuals (Pardhan, 2005). According to these researchers, becoming an effective science teacher in Pakistan depends on the acquisition of reflective skills and pedagogical knowledge through personal learning experiences, support, and training received from other professionals. A synthesis of key features and major findings of research on Pakistani science teachers' learning experiences through PD are presented in Table 2. A brief description of each of those PD programs' key features and major findings also follows.

\section{Knowledge and beliefs construction}

Teachers' personal knowledge and beliefs, along with professional pedagogical knowledge, could influence PD practices. Beliefs about learning and teaching science are developed through different sources like teachers' personal experiences as students and professional experiences as science teachers (Begum, 2012; Mahmood, 2013). Different researchers in Pakistan recommended that for adequate development of PD programs, science teachers' existing ideas, beliefs, experiences, concerns, interest and feelings toward learners, instruction, and organizations must be understood and inculcated in the structure of such programs (Iqbal et al., 2009; Pardhan, 2003; Perveen and Bhutta, 2012; Saeed and Mahmood, 2002; Shah, 2009). Asghar et al. (2012) mentioned that dynamic interactions between religious, cultural, and scientific spheres of learning come into play, and due to this, teachers' instructional practices are influenced. Research conducted in Pakistan recognized the contextualized and personalized nature of science teachers' knowledge construction during PD programs (Halai and McNicholl, 2004). Many PD programs served to shift science teachers' knowledge such as changing their perception of science from being a collection of facts to an enquiry-based subject. According to Halai (2011), the most appropriate PD learning experiences for science teachers in knowledge construction were working on enquiry tasks.

\section{Learning needs}

The learning needs of Pakistani science teachers are shaped through their command of knowledge and the context in which they work. Those PD programs that are efficient in meeting the distinct learning needs of teachers are the most effective types of programs. The majority of the literature on science teachers' learning and experiences in Pakistan indicated that science teachers' PD courses were highly inflexible and not designed or implemented in ways that are helpful to science teachers (Akhtar et al., 2011). However, effective PD programs that meet teachers' learning needs enabled them to increase high efficacy and strengthen skills to meet instructional challenges (Vazir, 2003). The research likewise found that for any PD program to be effective in Pakistan, it must focus on the needs of the teachers (Akhtar et al., 2011; Chaudary and Imran, 2012).

\section{Reflective practices}

The positive features of reflective practices were determined through the perception of improvement activities, equality of treatment, learning culture and effectiveness of school leadership (Alam, 2012; Shamim and Halai, 2006; Westbrook et al., 2009). Halai (2011) found that the knowledge science teachers bring to the classroom could not adequately assist them in teaching and completing their tasks. To be effective, they need a deeper understanding of the content they teach. A science teacher can learn and change his/her practices through continuous efforts

\begin{tabular}{|c|c|c|}
\hline Features & Major findings & Researcher(s) \\
\hline $\begin{array}{l}\text { Knowledge and beliefs } \\
\text { construction }\end{array}$ & $\begin{array}{l}\text { Science teachers' PD knowledge construction } \\
\text { are influenced by their personal knowledge } \\
\text { as well as professional experiences }\end{array}$ & $\begin{array}{l}\text { Ali, 2011; Begum, 2012; Halai, 2006; Halai and Khan, } \\
\text { 2011; Halai and McNicholl, 2004; Iqbal et al., 2009; } \\
\text { Pardhan, 2005; Perveen and Bhutta, 2012; Mahmood, } \\
\text { 2013; Shah, 2009; Tahir, 2010; Thomas, } 2013\end{array}$ \\
\hline Learning needs & $\begin{array}{l}\text { What they already know and what they need } \\
\text { to learn are not considered in PD }\end{array}$ & $\begin{array}{l}\text { Akhtar et al., 2011; Chaudary and Imran, 2012; Haider } \\
\text { and Ali, 2012; Iqbal and Mahmood, 2000; Vazir, } 2003\end{array}$ \\
\hline Teacher research & $\begin{array}{l}\text { Teachers learn through their action research } \\
\text { opportunities to improve their practices }\end{array}$ & $\begin{array}{l}\text { Halai, 2011; Halai and McNicholl, 2004; Mahmood, } \\
\text { 2013; Pardhan, 2005; Penny et al., 2000; Retallick and } \\
\text { Mithani, } 2003\end{array}$ \\
\hline Reflective practices & $\begin{array}{l}\text { Investigation of implemented knowledge } \\
\text { should be carried out to identify reflective } \\
\text { practices. These reflective practices are } \\
\text { influenced by several factors }\end{array}$ & $\begin{array}{l}\text { Alam, 2012; Halai, 2011; Halai and Khan, 2011; Khan } \\
\text { and Begum, 2012; Mahmood, 2013; Pardhan, 2003; } \\
\text { Shamim and Halai, 2006; Westbrook et al., } 2009\end{array}$ \\
\hline Communities of practice & $\begin{array}{l}\text { Communities of professional impacted the } \\
\text { creation and management of PD knowledge }\end{array}$ & $\begin{array}{l}\text { Ali, 2011; Hashmi, 2011; Shah, 2009; Westbrook et al., } \\
2009\end{array}$ \\
\hline $\begin{array}{l}\text { Attitudes for PD learning } \\
\text { and experience }\end{array}$ & $\begin{array}{l}\text { Teachers' attitudes can change PD learning } \\
\text { and experiences and participation }\end{array}$ & $\begin{array}{l}\text { Aslam, 2013; Halai, 2005; Iqbal and Shayer, 2000; } \\
\text { Nadeem et al., 2013; Tahir, } 2010\end{array}$ \\
\hline
\end{tabular}


of reflection on his or her learned knowledge (Halai, 2005). Mahmood (2013) found that the improvement of PD practices in Pakistan is significantly dependent on the development of reflective practices.

\section{Teacher research}

Studies pertaining to teacher research or action research in Pakistan indicated that science teachers perceived benefits as they become more reflective and made use of what they learned through action-research in improving their teaching and learning practices (Halai, 2011; Halai and Khan, 2011; Mahmood, 2013; Pardhan, 2005; Penny et al., 2000). Halai (2011) found that action research assisted teachers in expanding their knowledge base in three domains of knowledge: Content, pedagogical, and pedagogical CK.

\section{Communities of practice}

In Pakistan, the organizational structures such as communities of practice are shaped informally and through social interactions among science teachers. These practices assist science teachers in creating and managing PD knowledge and enhancing their learning abilities. Hashmi's (2011) research on professional learning communities in Pakistan revealed that working in such communities was perceived as a positive experience among science teachers. Positive impact of those activities on student achievement and organizational commitments was also observed (Shah, 2012). Further, research suggested that PD learning and experiences of teachers in Pakistan should focus on promoting group work and activity-based learning initiatives (Westbrook et al., 2009).

\section{Attitudes for PD learning}

Science teachers' PD learning is dependent on their positive attitudes and meaningful learning experiences, as well as how they position themselves as learners during PD (Halai, 2005; Nadeem et al., 2013). PD programs in Pakistan are shifting from the non-reflective attitudes to more reflective stance. Iqbal and Shayer (2000) found that a favorable teaching environment with access to proper resources was connected to the motivation of science teachers and their willingness to improve their professional skills. Aslam (2013) concluded that where there was a lack of teachers' involvement in PD planning and training process, there was a lack of interest in and weak attitudes toward PD programs. Similarly, Tahir (2010) observed that those PD activities in which teachers were involved in developing, practicing, and critiquing materials for field experiences were valued more than those that provided ordinary materials. He claimed that success of PD learning depends on the participants' attitudes toward PD and access to experiences in which teachers could actively participate.

\section{Issues Observed in the Effectiveness of PD Programs in Pakistani Context}

The research revealed that the nature of most of the PD programs in the public sector was more theoretical than practical and failed to address real-life scenarios of the teaching environment. A key challenge faced by Pakistani science teachers is the lack of relevance of PD programs to their learning needs (UNESCO, 2015). PD programs are characterized by an inflexible curriculum, which ignores the needs and working conditions of teachers (Akhtar et al., 2011; Aslam, 2013; Haider and Ali, 2012; Iqbal and Mahmood, 2000; Vazir, 2003).

It is a fact that most public-sector schoolteachers have poor subject matter knowledge (Government of Pakistan, 2012). Science teachers' PD programs, in general, consist of several short courses or workshops wherein insufficient pedagogical knowledge is provided to the teachers. Levine (2006) reported that PD learning and experiences were not aligned with their school curriculum, did not include adequate opportunities to practice what was taught, and inferior instruction (Levine, 2006). In addition, literature emphasized the structural and organizational issues in PD learning and experiences, while ignoring the philosophical, conceptual, and pedagogical underpinnings to PD practices (Ali, 2011).

While some PD opportunities helped teachers to reflect critically on aspects of teaching and learning, for example, knowledge, and beliefs about content, pedagogy, and learners, most of the PD practices indicated there were less opportunities for teachers to reflect on those aspects of teaching and learning, thus they remained less productive (Mahmood, 2013; Shah, 2009). Thomas (2013) mentioned that both professionally qualified and professionally unqualified teachers in Pakistan were not significantly different in their beliefs regarding pedagogical CK and utilization of constructivist approaches like student-centered approaches because of their beliefs system. According to Thomas and others (e.g., Hashmi, 2011; Pardhan, 2003), PD opportunities failed to address those pedagogical content issues.

Many studies revealed that contextual and cultural factors appeared to be a hindrance as to changing the instructional practices of teachers. Indeed, contextual and cultural factors weakened teachers' PD learning as a result most of the PD learning and experiences was not transferred to the classroom (Aslam, 2013).

Science teachers in Pakistan stated that it is essential to have social and professional support systems for effective practices (Ali, 2011). However, teachers are unaware of the role of the professional learning community and were found to be reluctant in accepting feedback from their colleagues. Halai (2005) emphasized the need for monitoring teachers' performance and suggested that timely feedback should be provided on their teaching styles and techniques. Most teachers prefer to work in isolation rather than sharing their knowledge among others. Due to the lack of communication between teachers and authorities, they regard themselves as consumers of PD programs rather than contributors (Haider and Ali, 2012; Halai, 2011; Nadeem et al., 2013; Rizvi and Elliott, 2005). To summarize, much of the literature on PD studies in Pakistan laid emphasis on the centrality of science teachers in the PD process. However, there was a strong tendency to overlook the conceptual and pedagogical supporting factors such as active 
learning, research, and follow-up strategies. The results and methodologies used were in conformity with the international narrative of PD learning and experiences. The next section examines the research questions in light of the current findings.

\section{DISCUSSION AND CONCLUSIONS}

The research questions that guided this literature review were:

1. What is the focus of the literature review on science teachers' PD learning and experiences in the Western context? How do the different features of PD learning and experiences support or impede PD effectiveness?

2. What is the focus of the literature review on science teachers' PD learning and experiences in the Pakistani context? How do the different features of PD learning and experiences support or impede PD effectiveness? and

3. What implications does the information gathered from the literature review have for Pakistani policymakers and researchers for developing research programs in studying PD programs and designing effective PD programs?

This literature review was compiled from 200 peer-reviewed research articles, with more than $75 \%$ belonging to the Western context (USA and European countries). The literature review for Pakistan included research articles and a few policy documents on science teachers. This literature was analyzed to understand the comparative features (Tables 1 and 2).

Overall, the literature review highlights the impacts of PD programs on teacher learning and experiences both in Western and Pakistani contexts. Researchers in the Western contexts are more focused on the active involvement of teachers, learning needs, knowledge construction through research and reflective practices, an alignment of $\mathrm{PD}$ with standards, PD practices and leadership roles, and so on. (Buczynski and Hansen, 2010; Corte et al., 2013; Lotter et al., 2013; Luneta, 2012; Posnanski, 2010; Saylor and Johnson, 2014; Towndrow et al., 2010).

Whereas in Pakistan, the focus seems to be on teachers' belief, knowledge construction, and PD implementation issues (Begum, 2012; Halai, 2006; Pardhan, 2005). A comparative review of the research findings in both contexts on science teachers' PD learning and experiences are presented in Table 3, the similarities and differences found in both types of literature on the features of PD learning.

The literature both in Pakistani and Western contexts emphasized that the active role of a science teacher, teachers' personal circumstances, and learning needs should be considered while designing and implementing PD activities (Begum, 2012; Borko, 2004; Darling-Hammond and Bransford, 2005; Jita and Mokhele, 2014; Luneta, 2012; Rizvi and Elliot, 2007). However, in countries like Pakistan, PD models such as the "cascade model" or "deficit model" are planned in the formal settings, inadvertently perpetuating the deficits in teacher performance because teachers are not given any autonomy. The disparities between science teachers' needs and governmental priorities for PD learning are not considered.
Hence, science teachers' PD practices are unable to respond to PD implementation requirement effectively. Similarly, PD practices were irrelevant to classroom and school realities. As less focus was placed on the practical work, most science teachers became less motivated and were passive participants within the PD programs.

Another significant similarity of the literature in both Pakistani and Western context is recognizing the complexities of the belief system and knowledge construction as a challenge for effective PD learning and experiences. Recent works in the Western world revealed the complexity of teachers' beliefs systems and the relationship with instructional practices (Fletcher and Luft, 2011; Smith and Lindsay, 2016). However, in Pakistan, like other non-Western countries, construction and internalization of scientific knowledge are different due to science teachers' perceptions about scientific knowledge. Most of them labeled this knowledge as "Western Science" and were resistant to learning in this context which made attitudes even more problematic (Ali, 2011; Aslam, 2013; Halai, 2005). Similarly, Pakistani PD practices were provided through a single workshop, or best a series of sessions that have limited impact in changing their beliefs and knowledge construction, whereas contextual and societal factors omitted from PD have influences on teachers' teaching and learning experiences (Halai, 2011).

Another conformity of Pakistani literature with that of the Western countries' literature was an emphasis on new PD learning pedagogies such as action research, enquiry-based learning, and collaborative or participatory activities. The literature in both contexts recommended an active link between science PD training bodies and the schools where trainees are employed to strengthen and support the PD learning experiences and transform science teachers as reflective practitioners. Emphasis was built on creating common knowledge, common practices, and relevant pedagogies to achieve better PD learning and experience for science teachers. The difference in Pakistani PD practices is that science teachers have no such opportunities available to build their reflective practices, which limits their opportunities to become part of a professional learning community (Ali, 2011; Hashmi, 2011; Pardhan, 2005). A distinctive feature of the literature in the Western context points to the fact that PD learning and experiences had a positive effect on teachers' learning and was supported by features such as school leadership, organizational support, and follow-up activities (Coenders and Terlouw, 2015; Delvaux et al., 2013; Opfer and Pedder, 2011; Rhoton and McLean, 2008). However, the literature in Pakistani context was found to be not focused on this significant feature of leadership. Mostly, teachers thought that the roles of school leadership were ineffective due to lack of guidance, limited resource, and cultural issues embedded in the school context.

In both Pakistani and Western contexts, the literature described the significance of PD learning in changing the attitudes of teachers. However, this attitude change is a complex process 


\begin{tabular}{|c|c|c|c|}
\hline PD learning features & $\begin{array}{l}\text { Pakistani findings like the } \\
\text { Western context }\end{array}$ & $\begin{array}{l}\text { Differences/issues in Pakistani } \\
\text { context }\end{array}$ & Implications for Pakistan \\
\hline $\begin{array}{l}\text { Active learning } \\
\text { experiences }\end{array}$ & $\begin{array}{l}\text { Researchers emphasize the active } \\
\text { participation of science teachers }\end{array}$ & No differences were observed & $\begin{array}{l}\text { Effective PD learning can be achieved through } \\
\text { active learning strategies in designing and } \\
\text { implementation }\end{array}$ \\
\hline Learning needs & $\begin{array}{l}\text { Meeting learning needs can } \\
\text { impact on teachers' efficacy to } \\
\text { meet teaching challenges }\end{array}$ & $\begin{array}{l}\text { PD curriculum is not flexible } \\
\text { and relevant to science teachers' } \\
\text { needs and ignored their working } \\
\text { conditions }\end{array}$ & $\begin{array}{l}\text { PD should be focused, cohesive and aligned with } \\
\text { teachers' needs and working conditions. }\end{array}$ \\
\hline \multirow[t]{3}{*}{$\begin{array}{l}\text { Beliefs and knowledge } \\
\text { constructions }\end{array}$} & \multirow[t]{3}{*}{$\begin{array}{l}\text { Beliefs and knowledge } \\
\text { construction of science teachers } \\
\text { must be comprehended and } \\
\text { inculcated in PD programs to } \\
\text { increase its effectiveness }\end{array}$} & $\begin{array}{l}\text { PD programs ignored the } \\
\text { philosophical, conceptual, and } \\
\text { pedagogical underpinning of } \\
\text { science teacher beliefs and } \\
\text { knowledge }\end{array}$ & \multirow[t]{3}{*}{$\begin{array}{l}\text { Beliefs change must be evaluated and considered } \\
\text { in PD learning and experiences. Changes in } \\
\text { Teacher CK and PCK must be assessed as } \\
\text { indicators of PD learning }\end{array}$} \\
\hline & & $\begin{array}{l}\text { Teachers' attitudes are less } \\
\text { favorable for learning }\end{array}$ & \\
\hline & & $\begin{array}{l}\text { The duration of PD is not enough } \\
\text { for knowledge construction nor } \\
\text { consistent with the practices }\end{array}$ & \\
\hline \multirow[t]{2}{*}{ Reflective practices } & \multirow[t]{2}{*}{$\begin{array}{l}\text { Reflective practices serve as } \\
\text { positive features in learning and } \\
\text { improvement of science teachers }\end{array}$} & $\begin{array}{l}\text { Opportunities for reflective for } \\
\text { science teachers' practices are less } \\
\text { available }\end{array}$ & \multirow[t]{2}{*}{$\begin{array}{l}\text { More emphasis should be put on science teachers' } \\
\text { opportunities to learn and reflect on their PD } \\
\text { practices }\end{array}$} \\
\hline & & $\begin{array}{l}\text { Reflective practices are only } \\
\text { technical in nature }\end{array}$ & \\
\hline Teacher research & $\begin{array}{l}\text { Helping in learning of all } \\
\text { knowledge domains and in } \\
\text { changing practices }\end{array}$ & $\begin{array}{l}\text { Teacher research is a neglected } \\
\text { area among science teachers for PD } \\
\text { learning and change }\end{array}$ & $\begin{array}{l}\text { An active research culture should be promoted } \\
\text { among science teachers to promote flexible } \\
\text { learning and change }\end{array}$ \\
\hline \multirow[t]{2}{*}{$\begin{array}{l}\text { Communities of } \\
\text { practices }\end{array}$} & \multirow[t]{2}{*}{$\begin{array}{l}\text { It assists in creating and } \\
\text { managing PD knowledge for } \\
\text { teachers }\end{array}$} & $\begin{array}{l}\text { Teachers are unaware of their role } \\
\text { in communities of practices and its } \\
\text { significance }\end{array}$ & \multirow[t]{2}{*}{$\begin{array}{l}\text { Communication between science teachers } \\
\text { and authorities must be promoted to build a } \\
\text { professional learning community }\end{array}$} \\
\hline & & $\begin{array}{l}\text { Most science teachers prefer to } \\
\text { work in isolation }\end{array}$ & \\
\hline $\begin{array}{l}\text { Leadership and } \\
\text { organizational support/ } \\
\text { follow-up }\end{array}$ & \multicolumn{2}{|c|}{ No literature was encountered in the Pakistani context } & $\begin{array}{l}\text { Effective leadership roles are required among } \\
\text { science teachers and principals to support PD } \\
\text { learning }\end{array}$ \\
\hline $\begin{array}{l}\text { Participation } \\
\text { experiences }\end{array}$ & $\begin{array}{l}\text { PD Learning is dependent } \\
\text { on positive and meaningful } \\
\text { participation experiences }\end{array}$ & $\begin{array}{l}\text { Traditional models of PD viewed } \\
\text { science teachers as deficits of } \\
\text { knowledge, hence discouraging } \\
\text { their participation }\end{array}$ & $\begin{array}{l}\text { Teacher-centered models of PD learning are } \\
\text { needed for effective practices among science } \\
\text { teachers }\end{array}$ \\
\hline $\begin{array}{l}\text { Attitudes towards PD } \\
\text { learning }\end{array}$ & $\begin{array}{l}\text { PD learning plays a significant } \\
\text { role in changing teachers' } \\
\text { attitudes }\end{array}$ & $\begin{array}{l}\text { PD is less supported by } \\
\text { policies and resources, and } \\
\text { non-involvement in PD activities } \\
\text { also impact on their learning }\end{array}$ & $\begin{array}{l}\text { PD must be designed according to improve } \\
\text { teachers' attitudes toward learning }\end{array}$ \\
\hline
\end{tabular}

CK: Content knowledge, PD: Professional development

and depends on policies and resources. Teachers' approaches to learning appear to be subject to individual experiences within the context of cultural norms (Demir and Ellett, 2014). Teachers in Pakistan need to be motivated to learn through effective practices. Their experiences must be recognized as being relevant and valuable through PD structure, designs, and objectives. Finally, effective PD should include opportunities for teachers to reflect on their pedagogical beliefs and practices.

\section{IMPLICATIONS FOR FUTURE RESEARCH}

As highlighted, a significant finding in this comparative literature review is that PD learning and experiences in Pakistan need to be built around the science teachers' needs and practices. Thus, policymakers and developers need to promote and adopt such learning models that actively involve teachers in the design and implementation of PD programs while addressing each teacher's needs. Similarly, teachers should be provided with incentives to participate in such activities. The beliefs and knowledge construction processes of science teachers in Pakistan should be studied more in-depth.

The comparisons in Table 3 indicate the need for sincere and focused dialogue in Pakistan about on what PD learning and experience depend and what needs to be done to promote the inclusion of cultural norms, reflective practices, and communities of practices. There is a need for effective teacher leaders and school leaders for PD programs in Pakistan, who are flexible, visionary, resourceful in both content and pedagogical $\mathrm{CK}$ and able to interact with science teachers. 
Leadership should be required and equipped to establish an environment in which science teachers feel empowered and motivated to learn.

A significant finding from the review of the Pakistani literature was that there is a shortage of published empirical research studies on the science teachers' learning and experiences, especially with teachers working in public schools. While building PD research and development culture, stakeholders need to reevaluate existing PD policies and programs in the light of findings in the literature. While the literature in the Western context is useful, further investigations can be done on the effectiveness of PD learning and experiences in Pakistan through understanding the enactment and implementation of PD policies. In the future, PD research in Pakistan should consider the following key questions: Can PD learning and experiences be generalized across the disciplines? How can the development of science as professionals be effective for increasing student achievement? How can stakeholders ensure the effectiveness of PD learning at changing science teachers' beliefs and views about NOS? How can science teachers' PD learning and experiences be differentiated across PD programs in different regions of Pakistan? How can the PD trainers' role influence the learning and experiences of their trainee? What models of PD learning could be suitable for Pakistani context?

The importance of cultural and contextual factors has drawn the attention of researchers around the world (Demir and Ellett, 2014). Future studies in Pakistan could extensively explore the relationship between the science teachers' learning activities, outcomes, and regulation of learning so that an improved system for science teachers' PD learning and experiences could be design and implemented.

\section{REFERENCES}

Adamson, K., Santau, A., \& Lee, O. (2013). The impact of professional development on elementary teachers' strategies for teaching science with diverse student groups in urban elementary schools. Journal of Science Teacher Education, 24, 553-571.

Aflalo, E. (2013). Religious belief: The main impact on the perception of the nature of science on student teachers. Cultural Studies of Science Education, 8, 623-641.

Akhtar, S.H., Shah, S., \& Naseer-ud-din, M. (2011). A critical analysis of the existing status of the in-service training of teachers at secondary level in Khyber Pakhtunkhwa (Pakistan). International Journal of Academic Research, 3, 417.

Akiba, M. (2012). Professional learning activities in context: A statewide survey of middle school mathematics teachers. Education Policy Analysis Archives, 20(14), 1-33.

Alam, S. (2012). Crafting leaders for educational change: Head teacher's perspectives. International Journal of Social Sciences and Education, 2(1), 193-210.

Ali, T. (2011). Understanding how practices of teacher education in Pakistan compare with the popular theories and narrative of reform of teacher education in international context. International Journal of Humanities and Social Sciences, 1(8), 208-222.

Allen, C.D., \& Penuel, W.R. (2015). Studying teachers' sense making to investigate teachers' responses to professional development focused on new standards. Journal of Teacher Education, 66(2), 136-149.

Antoniou, P., \& Kyriakides, L. (2013). A dynamic integrated approach to teacher professional development: Impact and sustainability of the effects on improving teacher behavior and student outcomes. Teaching and Teacher Education, 29, 1-12.

Asghar, A., Ellington, R., Rice, E., Johnson, F., \& Prime, G.M. (2012). Supporting STEM education in secondary science contexts. Interdisciplinary Journal of Problem-based Learning, 6(2), 85-125.

Aslam, H.D. (2013). Analysis of professional development practices for school teachers in Pakistan: A comparative case study of public and private schools of Pakistan (Punjab). International Journal of Human Resource Studies, 3, 311-326.

Atwater, M.M., Russell, M., \& Butler, M., (Eds.) (2013). Multicultural Science Education: Preparing Teachers for Equity and Social Justice. New York: Springer.

Banilower, E.R., Heck, D.J., \& Weiss, I.R. (2007). Can professional development make the vision of the standards a reality? The impact of the national science foundation's local systemic change through teacher enhancement initiative. Journal of Research in Science Teaching, 44, 375-395.

Baumfield, V. (2007). Teachers as learners: Promoting professional development through inquiry. Journal of Research and Reflections in Education, 1(2), 147-159.

Beamer, T., Van Sickle, M., Harrison, G., \& Temple, G. (2008). Lasting impact of a professional development program on constructivist science teaching. Journal of Elementary Science Education, 20(4), 49-60.

Begum, S. (2012). A secondary science teacher's beliefs about environmental education and its relationship with the classroom practices. International Journal of Social Sciences and Education, 2(1), 10-29.

Bell, C.V., \& Odom, A.L. (2012). Reflections on discourse practices during professional development on the learning cycle. Journal of Science Teacher Education, 23, 601-620.

Bernhardt, P.E. (2015). $21^{\text {st }}$ century learning: Professional development in practice. The Qualitative Report, 20(1), 1-19.

Berry, A., Loughran, J., Smith, K., \& Lindsay, S. (2009). Capturing and enhancing science teachers' professional knowledge. Research in Science Education, 39, 575-594.

Bocala, C. (2015). From experience to expertise the development of teachers' learning in lesson study. Journal of Teacher Education, 66, 349-362.

Borko, H. (2004). Professional development and teacher learning: Mapping the terrain. Educational Researcher, 33(8), 3-15.

Boyle, B., While, D., \& Boyle, T. (2004). A longitudinal study of teacher change: What makes professional development effective? Curriculum Journal, 15(1), 45-68.

Buczynski, S., \& Hansen, C.B. (2010). Impact of professional development on teacher practice: Uncovering connections. Teaching and Teacher Education, 26, 599-607.

Capobianco, B.M., \& Feldman, A. (2006). Promoting quality for teacher action research: Lessons learned from science teachers' action research. Educational Action Research, 14, 497-512.

Capobianco, B.M., Lincoln, S., Canuel-Browne, D., \& Trimarchi, R. (2006). Examining the experiences of three generations of teacher researchers through collaborative science teacher inquiry. Teacher Education Quarterly, 33(3), 61-78.

Chaudary, I.A., \& Imran, S. (2012). Listening to unheard voices: Professional development reforms for Pakistani tertiary teachers. Australian Journal of Teacher Education, 37(2), 88-97.

Çimer, S.O., \& Paliç, G. (2012). Teachers' perceptions and practices of reflection. International Journal of Educational Research and Technology, 3(1), 52-60.

Coenders, F., \& Terlouw, C. (2015). A model for in-service teacher learning in the context of an innovation. Journal of Science Teacher Education, $26,451-470$

Coenders, F., Terlouw, C., Dijkstra, S., \& Pieters, J. (2010). The effects of the design and development of a chemistry curriculum reform on teachers' professional growth: A case study. Journal of Science Teacher Education, 21, 535-557.

Corte, M.V.D., Brok, P.D., Kamp, M., \& Bergen, T. (2013). Teacher research in Dutch professional development schools: Perceptions of the actual and preferred situation in terms of the context, process and outcomes of research. European Journal of Teacher Education, 36(1), 3-23.

Cox-Petersen, A.M., Spencer, B.H., \& Crawford, T.J. (2005). Developing a community of teachers through integrated science and literacy servicelearning experiences. Issues in Teacher Education, 14(1), 23-37. 
Crippen, K.J. (2012). Argument as professional development: Impacting teacher knowledge and beliefs about science. Journal of Science Teacher Education, 23, 847-866.

Dare, E.A., Ellis, J.A., \& Roehrig, G.H. (2014). Driven by beliefs: Understanding challenges physical science teachers face when integrating engineering and physics. Journal of Pre-College Engineering Education Research (J-PEER), 4(2), 47-61.

Darling-Hammond, L., \& Bransford, J., (Eds.). (2005). Preparing Teachers for a Changing World: What Teachers should Learn and be Able to do. San Francisco, CA: John Wiley and Sons.

Daugbjerg, P.S., de Freitas, E., \& Valero, P. (2015). Mapping the entangled ontology of science teachers' lived experience. Cultural Studies of Science Education, 10, 777-801.

Delvaux, E., Vanhoof, J., Tuytens, M., Vekeman, E., Devos, G., \& Van Petegem, P. (2013). How may teacher evaluation have an impact on professional development? A multilevel analysis. Teaching and Teacher Education, 36, 1-11.

Demir, K., \& Ellett, C.D. (2014). Science teacher self-efficacy beliefs, change processes, and professional development. In: Evans, R., Luft, J., Czerniak, C., \& Pea, C., (Eds.), The Role of Science Teachers' Beliefs in International Classrooms. Rotterdam, The Netherlands: Sense Publishers. p179-190.

Deniz, H., \& Akerson, V. (2013). Examining the impact of a professional development program on elementary teachers' views of nature of science and nature of scientific inquiry, and science teaching efficacy beliefs. Electronic Journal of Science Education, 17(3), 1-19.

Desimone, L.M. (2009). Improving impact studies of teachers' professional development: Toward better conceptualizations and measures. Educational Researcher, 38, 181-199.

Desimone, L.M., Porter, A.C., Garet, M.S., Yoon, K.S., \& Birman, B.F. (2002). Effects of professional development on teachers' instruction: Results from a three-year longitudinal study. Educational Evaluation and Policy Analysis, 24(2), 81-112.

Diamond, B.S., Maerten-Rivera, J., Rohrer, R.E., \& Lee, O. (2014). Effectiveness of a curricular and professional development intervention at improving elementary teachers' science content knowledge and student achievement outcomes: Year 1 results. Journal of Research in Science Teaching, 51, 635-658.

Eilks, I., \& Markic, S. (2011). Effects of a long-term participatory action research project on science teachers' professional development. Eurasia Journal of Mathematics, Science and Technology Education, 7(3), 149-160.

El-Hani, C.N., \& Greca, I.M. (2013). ComPratica: A virtual community of practice for promoting biology teachers' professional development in Brazil. Research in Science Education, 43, 1327-1359.

Faber, C., Hardin, E., Klein-Gardner, S., \& Benson, L. (2014). Development of teachers as scientists in research experiences for teachers programs. Journal of Science Teacher Education, 25, 785-806.

Fletcher, S.S., \& Luft, J.A. (2011). Early career secondary science teachers: A longitudinal study of beliefs in relation to field experiences. Science Education, 95, 1124-1146.

Foster, J.M., Toma, E.F., \& Troske, S.P. (2013). Does teacher professional development improve math and science outcomes and is it cost effective? Journal of Education Finance, 38, 255-275.

Gao, S., \& Wang, J. (2014). Teaching transformation under centralized curriculum and teacher learning community: Two Chinese chemistry teachers' experiences in developing inquiry-based instruction. Teaching and Teacher Education, 44, 1-11.

Garet, M.S., Porter, A.C., Desimone, L., Birman, B.F., \& Yoon, K.S. (2001). What makes professional development effective? Results from a national sample of teachers. American Educational Research Journal, $38,915-945$

Goodnough, K. (2010). The role of action research in transforming teacher identity: Modes of belonging and ecological perspectives. Educational Action Research, 18(2), 167-182.

Government of Pakistan. (2009). National Education Policy 2009. Available from: http://www.itacec.org/document/2015/7/National_Education Policy_2009.pdf. [Last accessed on 2019 Jun 14].

Government of Pakistan. (2012). National Science, Technology and Innovation Policy 2012. Islamabad, Pakistan: Ministry of Science and Technology.
Government of Punjab. (2012). In-Service Training for Professional Development. Lahore, Pakistan: Directorate of Staff Development.

Greene, B.A., Lubin, I.A., Slater, J.L., \& Walden, S.E. (2013). Mapping changes in science teachers' content knowledge: Concept maps and authentic professional development. Journal of Science Education and Technology, 22, 287-299.

Guskey, T.R. (2002). Professional development and teacher change. Teachers and Teaching: Theory and Practice, 8, 381-391.

Guskey, T.R., \& Yoon, K.S. (2009). What works in professional development. Phi Delta Kappan, 90, 495-500.

Haider, S.Z., \& Ali, R. (2012). Teacher training at secondary level in Pakistan: Provisions and condition. International Journal of Social Sciences and Education, 2(1), 551-566.

Halai, N. (2005). Teachers' experiences of learning science: A case of autobiographical reflection. Science Education International, 16(4), 237-242.

Halai, N. (2006). Reconceptualising the professional development of inservice science teachers in Pakistan. In: Earnest, J., \& Treagust, D., (Eds.), Education Rebuilding in Societies in Transition: International Perspectives. Rotterdam, Netherlands: Sense Publications. p163-176.

Halai, N. (2011). How teachers become action researchers in Pakistan: Emerging patterns from a qualitative metasynthesis. Educational Action Research, 19, 201-214.

Halai, N., \& Khan, M.A. (2011). Developing pedagogical content knowledge of science teachers through action research: A case study from Pakistan. Asia Pacific Forum on Science Teaching and Learning, 12(1), 1-23.

Halai, N., \& McNicholl, J. (2004). Teachers' conceptions of the nature of science: A comparative study from Pakistan and UK. School Science Review, 86(314), 93-100.

Hargreaves, A., \& Shirley, D. (2012). The Global Fourth Way: The Quest for Educational Excellence. Thousand Oaks, CA: Corwin Press.

Harnett, J. (2012). Reducing discrepancies between teachers' espoused theories and theories-in-use: An action research model of reflective professional development. Educational Action Research, 20, 367-384.

Hashmi, K. (2011). Professional learning community: A study of teachers' perceptions in Pakistan. International Journal of Social Sciences and Education, 1, 474-480.

Heck, D.J. \& Crawford, R.A. (2004). LSC Teacher Questionnaire Study: A Longitudinal Analysis of Data Collected between 1997 and 2003. Chapel Hill, NC: Horizon Research, Inc.

Henze, I., van Driel, J.H., \& Verloop, N. (2009). Experienced science teachers' learning in the context of educational innovation. Journal of Teacher Education, 60, 184-199.

Herman, B.C., Clough, M.P., \& Olson, J.K. (2013). Association between experienced teachers' NOS implementation and reform-based practices. Journal of Science Teacher Education, 24, 1077-1102.

Hermann, R.S. (2013). High school biology teachers' views on teaching evolution: Implications for science teacher educators. Journal of Science Teacher Education, 24, 597-616.

Hobbs, L. (2012). Teaching out-of-field: Factors shaping identities of secondary science and mathematics. Teaching Science: The Journal of the Australian Science Teachers Association, 58(1), 21-29.

Holbrook, J, Rannikmäe, M., \& Valdmann, A. (2014). Identifying teacher needs for promoting education through science as a paradigm shift in science education. Science Education International, 25(2), 133-171.

Howe, A.C., \& Stubbs, H.S. (2003). From science teacher to teacher leader: Leadership development as meaning making in a community of practice. Science Education, 87, 281-297.

Hynds, A., Sleeter, C., Hindle, R., Savage, C., Penetito, W., \& Meyer, L.H. (2011). The induction outcomes. Teaching and Teacher Education, 27, 861-870.

Imants, J. (2002). Restructuring schools as a context for teacher learning. International Journal of Educational Research, 37, 715-732.

Iqbal, H.M., \& Mahmood, N. (2000). Science teacher education in Pakistan. In: Abell, S.K., (Ed.), Science Teacher Education: An International Perspective. Boston, MA: Kluwer. p75-92.

Iqbal, H.M., \& Shayer, M. (2000). Accelerating the development of formal thinking in Pakistan secondary school students: Achievement effects and professional development issues. Journal of Research in Science Teaching, 37, 259-274. 
Iqbal, H.M., Azam, S., \& Rana, R.A. (2009). Secondary school science teachers" views about the "nature of science." Bulletin of Education and Research, 31(2), 29-44.

Jita, L.C., \& Mokhele, M.L. (2014). When teacher clusters work: Selected experiences of South African teachers with the cluster approach to professional development. South African Journal of Education, 34(2), $1-15$.

Kazempour, M. (2009). Impact of inquiry-based professional development on core conceptions and teaching practices: A case study. Science Educator, 18(2), 56

Kazempour, M., \& Amirshokoohi, A. (2014). Transitioning to inquirybased teaching: Exploring science teachers' professional development experiences. International Journal of Environmental and Science Education, 9, 285-309.

Khan, B., \& Begum, S. (2012). Portfolio: A professional development and learning tool for teachers. International Journal of Social Science and Education, 2, 363-377.

Kwakman, K. (2001). Work stress and work-based learning in secondary education: Testing the Karasek model. Human Resource Development International, 4, 487-501.

Lalor, B., \& Abawi, L. (2014). Professional learning communities enhancing teacher experiences in international schools. International Journal of Pedagogies and Learning, 9(1), 76-86.

Lee, O., \& Buxton, C.A. (2013). Teacher professional development to improve science and literacy achievement of English language learners. Theory into Practice, 52(2), 110-117.

Levine, A. (2006). Educating School Teachers. Education Schools Project. Available from: http://www.edschools.org/pdf/Educating_Teachers_ Report.pdf. [Last accessed on 2019 Jun 14].

Lieberman, A., \& Mace, D.H.P. (2008). Teacher learning: The key to educational reform. Journal of Teacher Education, 59, 226-234.

Lotter, C., Rushton, G.T., \& Singer, J. (2013). Teacher enactment patterns: How can we help move all teachers to reform-based inquiry practice through professional development? Journal of Science Teacher Education, 24, 1263-1291.

Loucks-Horsley, S., Stiles, K.E., Mundry, S., Love, N., \& Hewson, P.W. (2009). Designing Professional Development for Teachers of Science and Mathematics. Thousand Oaks, CA: Corwin Press.

Loughran, J. (2013). Pedagogy: Making sense of the complex relationship between teaching and learning. Curriculum Inquiry, 43(1), 118-141.

Lovett, S., \& Cameron, M. (2011). Schools as professional learning communities for early-career teachers: How do early-career teachers rate them? Teacher Development, 15(1), 87-104.

Luft, J.A. \& Hewson, P.W. (2014). Research on teacher professional development programs in science. In: Lederman, N.G., \& Abell, S., (Eds.), Handbook of Research in Science Education. Vol. 2. New York: Routledge. p889-909.

Luneta, K. (2012). Designing continuous professional development programmes for teachers: A literature review. Africa Education Review, 9, 360-379.

Lustick, D.S. (2011). Experienced secondary science teachers' perceptions of effective professional development while pursuing national board certification. Teacher Development, 15, 219-239.

Mahmood, N. (2013). Classroom practices and consequent transformation in beliefs towards science teaching: A case study of elementary school science teacher. Ankara University, Journal of Faculty of Educational Sciences, 46, 297-315.

Mamlok-Naaman, R., \& Eilks, I. (2012). Different types of action research to promote chemistry teachers' professional development a joined theoretical reflection of two cases from Israel and Germany. International Journal of Science and Mathematics Education, 10, 581-610.

Maskit, D. (2013). First months in teaching novices relate to their difficulties. Creative Education, 4(4), 1-8.

Masuda, A.M., Ebersole, M.M., \& Barrett, D. (2013). A qualitative inquiry: Teachers' attitudes and willingness to engage in professional development experiences at different career stages. Delta Kappa Gamma Bulletin, 79(2), 6-14.

McCullagh, J.F. (2012). How can video supported reflection enhance teachers' professional development? Cultural Studies of Science Education, 7(1), 137-152.
McCullough, G., Helsby, G., \& Knight, P. (2000). The Politics of Professionalism. London: Continuum.

McNeill, K.L., \& Knight, A.M. (2013). Teachers' pedagogical content knowledge of scientific argumentation: The impact of professional development on K-12 teachers. Science Education, 97, 936-972.

McNicholl, J., \& Blake, A. (2013). Transforming teacher education, an activity theory analysis. Journal of Education for Teaching, 39, 281-300.

Melville, W., \& Yaxley, B. (2009). Contextual opportunities for teacher professional learning: The experience of one science. Eurasia Journal of Mathematics, Science and Technology Education, 5, 357-368.

Mikelskis-Seifert, S., \& Duit, R. (2013). Physics teachers' professional development in the project "physics in context". Cosmos: Journal of the Singapore National Academy of Science, 8, 211-227.

Mokhele, M.L., \& Jita, L.C. (2010). South African teachers' perspectives on continuing professional development: A case study of the Mpumalanga secondary science initiative. Procedia-Social and Behavioral Sciences, 9, 1762-1766.

Muir, T., Beswick, K., \& Williamson, J. (2010). Up, close and personal: Teachers' responses to an individualized professional learning opportunity. Asia-Pacific Journal of Teacher Education, 38, 129-146.

Nadeem, M., Chairman, A.A., Lone, A.H., \& Maqbool, S. (2013). An empirical study on teachers' perception of teachers training programmes provided in cantonment/garrisons schools of Pakistan. Journal of Educational and Instructional Studies in the World, 3(1), 121-126.

National Education Assessment System (NEAS). (2014). National Achievement Test-2014. Islamabad: Ministry of Federal Education, and Professional Training. Available from: http://www.neas.gov.pk/ Document\%20Center_files/National_Stakeholder_2014.pdf. [Last accessed on 2019 Jun 14].

Ngcoza, K., \& Southwood, S. (2015). Professional development networks: From transmission to co-construction. Perspectives in Education, $33(1), 1-11$.

Nielsen, B.L. (2012). Science teachers' meaning-making when involved in a school-based professional development project. Journal of Science Teacher Education, 23, 621-649.

Nir, A.E., \& Bogler, R. (2008). The antecedents of teacher satisfaction with professional development programs. Teaching and Teacher Education, $24,377-386$

Oliveira, A.W., Wilcox, K.C., Angelis, J., Applebee, A.N., Amodeo, V., \& Snyder, M.A. (2013). Best practice in middle-school science. Journal of Science Teacher Education, 24, 297-322.

Opfer, V.D., \& Pedder, D. (2011). The lost promise of teacher professional development in England. European Journal of Teacher Education, 34(1), 3-24.

Owston, R., Wideman, H., Murphy, J., \& Lupshenyuk, D. (2008). Blended teacher professional development: A synthesis of three program evaluations. The Internet and Higher Education, 11(3), 201-210.

Pardhan, H. (2003). Working with teachers: Practical suggestion stimulates teacher's self-reflection. Alberta Science Education Journal, 34(2), 47-54

Pardhan, H. (2005). Action research for female science teacher development: Case Pakistan. European Journal of Scientific Research, 6(1), 46-64.

Park, J., Martin, S.N., \& Chu, H.E. (2015). Examining how structures shape teacher and student agency in science classrooms in an innovative middle school: Implications for policy and practice. Journal of the Korean Association for Science Education, 35, 773-790.

Patton, K., Parker, M., \& Pratt, E. (2013). Meaningful learning in professional development: Teaching without telling. Journal of Teaching in Physical Education, 32, 441-459.

Penny, A.J., Ali, M.A., Farah, I., Ostberg, S., \& Smith, R.L. (2000). A study of cross-national collaborative research: Reflecting on experience in Pakistan. International Journal of Educational Development, 20, 443-455.

Perveen, N., \& Bhutta, S.M. (2012). Enhancing content knowledge of inservice science teachers through model and modeling. Journal of Research and Reflections in Education, 6(1), 61-74.

Petrie, K.C., \& McGee, C. (2012). Teacher professional development: Who is the learner? Australian Journal of Teacher Education, 37(2), 59-72.

Posnanski, T.J. (2010). Developing understanding of the nature of science within a professional development program for in-service elementary teachers: Project nature of elementary science teaching. Journal of Science Teacher Education, 21, 589-621. 
Ramlo, S. (2012). In-service science teachers' views of a professional development workshop and their learning of force and motion concepts. Teaching and Teacher Education, 28, 928-935.

Rathgen, E. (2006). In the voice of teachers: The promise and challenge of participating in classroom-based research for teachers' professional learning. Teaching and Teacher Education, 22, 580-591.

Retallick, J., \& Mithani, S. (2003). The impact of a professional development program: A study from Pakistan. Journal of In-service Education, 29, 405-422.

Rhodes, C., \& Beneicke, S. (2002). Coaching, mentoring and peernetworking: Challenges for the management of teacher professional development in schools. Journal of In-service Education, 28, 297-310.

Rhoton, J., \& McLean, J.E. (2008). Developing teacher leaders in science: Catalysts for improved science teaching and student learning. Science Educator, 17(2), 45-56.

Rizvi, M., \& Elliot, B. (2005). Teachers' perceptions of their professionalism in government primary schools in Karachi, Pakistan. Asia-Pacific Journal of Teacher Education, 33(1), 35-52.

Roseler, K., \& Dentzau, M.W. (2013). Teacher professional development: A different perspective. Cultural Studies of Science Education, $8,619-622$.

Roux, J.A. (2013). The Factors that Affect Science Teachers' Participation in Professional Development (Doctoral Dissertation). USA: University of Minnesota.

Saeed, M., \& Mahmood, K. (2002). Assessing competency of Pakistani primary school teachers in mathematics, science and pedagogy. International Journal of Educational Management, 16(4), 190-195.

Sandholtz, J.H., \& Ringstaff, C. (2016). The influence of contextual factors on the sustainability of professional development outcomes. Journal of Science Teacher Education, 27, 205-226.

Santos, M.D.C., \& Oliveira, M.T. (2006). A teacher's professional development training for a different kind of experimental work. European Journal of Vocational Training, 39(3), 115-129.

Saunders, R. (2012). Assessment of professional development for teachers in the vocational education and training sector: An examination of the concerns based adoption model. Australian Journal of Education, 56, 182-204.

Saylor, L.L., \& Johnson, C.C. (2014). The role of reflection in elementary mathematics and science teachers' training and development: A metasynthesis. School Science and Mathematics, 114, 30-39.

Scheerens, J. (2010). Teachers' Professional Development: Europe in International Comparison. A Secondary Analysis Based on the TALIS Dataset. Available from: http://www.bollettinoadapt.it/old/ files/document/4335TALISTEACHERSNOV.pdf. [Last accessed on 2019 Jun 14].

Seidel, T., Stürmer, K., Blomberg, G., Kobarg, M., \& Schwindt, K. (2011). Teacher learning from analysis of videotaped classroom situations: Does it make a difference whether teachers observe their own teaching or that of others? Teaching and Teacher Education, 27, 259-267.

Sexton, S.S., Atkinson, J., \& Goodson, R. (2013). Narratives of place: Provisional teachers' experiences in science. Science Education International, 24, 361-376.

Shah, M.Z. (2009). Exploring the conceptions of a science teacher from Karachi about the nature of science. Eurasia Journal of Mathematics, Science and Technology Education, 5, 305-315.

Shamim, F., \& Halai, A. (2006). Developing professional development teacher. In: Farah, I., \& Jaworski, B., (Eds.), Partnerships in Educational Development. Oxford: Symposium Books. p47-68.

Sinclair, B.B., Naizer, G., \& Ledbetter, C. (2011). Observed implementation of a science professional development program for K-8 classrooms. Journal of Science Teacher Education, 22, 579-594.

Smith, G. (2015). The impact of a professional development programme on primary teachers' classroom practice and pupils' attitudes to science. Research in Science Education, 45, 215-239.

Smith, K., \& Lindsay, S. (2016). Building future directions for teacher learning in science education. Research in Science Education, 46, 243-261.
Sullivan-Watts, B.K., Nowicki, B.L., Shim, M.K., \& Young, B.J. (2013). Sustaining reform-based science teaching of preservice and in-service elementary school teachers. Journal of Science Teacher Education, 24, 879-905

Tahir, A.Q. (2010). Review and improvement of elementary science training program. Journal of Educational Research, 13(2), 9776-1027.

Tan, Y.S.M., \& Nashon, S.M. (2013). Promoting teacher learning through learning study discourse: The case of science teachers in Singapore. Journal of Science Teacher Education, 24, 859-877.

Tang, X., \& Shao, F. (2014). On the evolution of a lesson: Group preparation for teaching contest as teacher professional development activity for Chinese elementary science teachers. Journal of Science Education and Technology, 23, 252-266.

Thomas, M. (2013). Teachers' beliefs about classroom teaching teachers' knowledge and teaching approaches. Procedia-Social and Behavioral Sciences, 89, 31-39.

Torff, B., \& Byrnes, K. (2010). Differences across academic subjects in teachers' attitudes about professional development. The Educational Forum, 75(1), 26-36).

Towndrow, P.A., Tan, A.L., Yung, B.H., \& Cohen, L. (2010). Science teachers' professional development and changes in science practical assessment practices: What are the issues? Research in Science Education, 40, 117-132.

Tytler, R., Symington, D., Darby, L., Malcolm, C., \& Kirkwood, V. (2011). Discourse communities: A framework from which to consider professional development for rural teachers of science and mathematics. Teaching and Teacher Education, 27, 871-879.

UNESCO. (2015). UNESCO Science Report: Towards 2030 Executive Summary. Available from: http://www.unesdoc.unesco.org/ images/0023/002354/235407e.pdf. [Last accessed on 2019 Jun 14].

van Driel, J.H., Beijaard, D., \& Verloop, N. (2001). Professional development and reform in science education: The role of teachers' practical knowledge. Journal of Research in Science Teaching, 38, 137-158.

Vazir, N. (2003). Curriculum as practiced in Pakistan. Journal of Educational Research, 6(1-2), 177-183.

Vázquez-Bernal, B., Mellado, V., Jiménez-Pérez, R., \& Leñero, M. (2012). The process of change in a science teacher's professional development: A case study based on the types of problems in the classroom. Science Education, 96, 337-363.

Visser, T.C., Coenders, F.G., Pieters, J.M., \& Terlouw, C. (2013). The learning effects of a multidisciplinary professional development programme. Journal of Science Education and Technology, 22, 807-824.

Wallace, C.S. (2013). Promoting shifts in preservice science teachers' thinking through teaching and action research in informal science settings. Journal of Science Teacher Education, 24, 811-832.

Westbrook, J., Shah, N., Durrani, N., Tikly, C., Khan, W., \& Dunne, M. (2009). Becoming a teacher: Transitions from training to the classroom in the NWFP, Pakistan. International Journal of Educational Development, 29, 437-444.

White, S., Bloomfield, D., \& Cornu, R.L. (2010). Professional experience in new times: Issues and responses to a changing education landscape. Asia-Pacific Journal of Teacher Education, 38(3), 181-193.

Whitworth, B.A., \& Chiu, J.L. (2015). Professional development and teacher change: The missing leadership link. Journal of Science Teacher Education, 26(2), 121-137.

Zhang, M., Parker, J., Koehler, M.J., \& Eberhardt, J. (2015). Understanding in-service science teachers' needs for professional development. Journal of Science Teacher Education, 26, 471-496.

Zientek, A. (2014). Effective Elements of Science Teacher Professional Development (Doctoral Dissertation). USA: The University of Wisconsin-Milwaukee.

Zwiep, S.G., \& Benken, B.M. (2013). Exploring teachers' knowledge and perception across mathematics and science through content rich learning experiences in a professional development. International Journal of Science and Mathematics Education, 11, 299-324. 